食道癌手術前後に扣ける糖代謝と膵内分泌機能に関する研究

\begin{tabular}{rrrrrr}
\multicolumn{8}{c}{ 近畿大学医学部第 2 外科 } & \\
須藤 & 峻章 & 白羽 & 誠 & 石山 & 堅司 \\
竹本 & 雅彦 & 浅川 & 隆 & 泉谷 & 良 \\
䓫蒲 & 隆治 & 河村 & 正生 & 大西 & 弘道 \\
梅村 & 博也 & 久山 & 健 & &
\end{tabular}

\title{
CLINICAL STUDY ON THE CARBOHYDRATE METABOLISM \\ AND PANCREATIC ENDOCRINE FUNCTION \\ AFTER ESOPHAGECTOMY
}

\author{
Takaaki SUDO, Sei SHIRAHA, Kenji ISHIYAMA, Masahiko TAKEMOTO, \\ Takashi ASAKAWA, Ryo IZUTANI, Ryuji SHOBU, \\ Masao KAWAMURA, Hiromichi OHNISHI, \\ Hiroya UMEMURA and \\ Takeshi KUYAMA
}

Second Department of Surgery, Kinki University School of Medicine

\begin{abstract}
食道癌患者は, 高齢者が多く, 大なり小なり糖代謝障害を来しているが, 食道癌の手術は, さらに 手術侵襲を加兄ることとなり, また食道切除に伴ら幹迷切の結果, 糖代謝に関与する膵内分泌機能, とくに, インスリン，グルカゴン分泌に影響を扰よぼするのと思われる。術前㧍よび術後 1 カ月に卜 レーラン G150ml を経口負荷し, 血糖値, インスリン值, グルカゴン值を测定するとともに, コントロー ル群と術後 1 カ月に経静脈的にブドウ糖 $0.5 \mathrm{~g} / \mathrm{kg}$ を注入し, 血糖値, インスリン值, グルカゴン值を 測定し,インスリン,グルカゴンの糖代謝に技よぼす影響について検討し, 次の結果を得た。経口負 荷試験では，食道癌患者は，コントロール群にくらべて，インスリン分泌機能は低下していたが，術 後は, インスリン分泌機能は, 早期には立進し, 後期には低下した。グルカゴン分泌は著明に六進し でり，食道癌手術後の糖代謝障害に高グルカゴン血症が関与していることが示唆された.

経静脈負荷試験では，術後はインスリン分泌反応とグルカゴン分泌抑制反応が低下しておう，幹迷 切の影響を強く受ける事が判明した。
\end{abstract}

索引用語：食道癌手術, 膵内分泌機能, インスリン, グルカゴン

近年麻酔, 輸夜, 抗生物質, および術前, 術後の管 理の進歩により高齢者に括いても，食道癌の手術を積 極的に扤こなうようになり，耐糖能の低下している患 者にさらに手術侵襲を加え, 高カロリー輸液をおこな ら機会が増えているが，糖代謝に関与する，インスリ ン,グルカゴン分泌の立場より食道癌手術後の糖代謝 に検討を加えたものは少ない。

食道癌の手術に括いては，食道切除に際し左右の全
幹迷走神経切除を行なっており，腪内分泌之くにイン スリン,グルカゴン分泌影響を招よぼし，ひいては， 食道癌手術後の糖代謝障害を来するのと思われる。

正常人之糖疗病患者の間には, インスリン值のみな らず, グルカゴン值に差異が認められ(2)，ある種の糖 尿病患者は，相対的グルカゴン分泌過剩下にあるとい

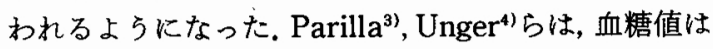
門脈血中インスリン濃度とグルカゴン濃度により左右 
されるとしており糖尿病におけるグルカゴンの役割が 強調されている，そこで，私達は術前術後にトレーラ ン G150ml を経口負荷し，糖代謝に関与するインスリ ン，グルカゴン分泌の立場より食道癌術前, 術後の糖 代謝について検討した。

\section{対象と方法}

対象は食道癌患者で, 年齢は52藏より73歳の男女 8 名とコントロール群，年齢50〜70歳の非糖尿病者 10 名 である。

1) 手術方法

著者の一人である白羽河による全胃後綎隔ルート挙 上による食道再建術を施行した。

2) 糖負荷試験

コントロール群10名と食道癌患者 8 名に術前および 術後 1 力月に, 一昼夜絶食後に前腕静脈より採血を行 い, トレラン G150ml 経口負荷後 15 分, 30 分, 60 分, 120 分に採血を行い, 血糖値, インスリン值, グルカゴン 値の測定に用いた。

3）血糖値，インスリン值，グルカゴン值の測定 血糖值の測定は O-Toluidine 法にて行った。インス リンの測定は，シオノギキットを使用した 2 抗体法に て測定した，グルカゴンの測定は，冷却スピッツに血 液 $1 \mathrm{ml}$ 当り，1,000単位のアプロチニン(Trasylol) と EDTA1.2mg を添加して採集し， $4{ }^{\circ} \mathrm{C}$ 以下で3,000r.p. m. で15分間遠沈し， $-20^{\circ} \mathrm{C}$ で凍結保存した。この凍結 血清は,アッセイ当日 $4{ }^{\circ} \mathrm{C}$ 以下で溶解し, Unger の30 $\mathrm{K}$ 抗体を使用した Charcol-dextran 法にて測定した。 測定数值はMeans \pm SEM で表わし，有意差検定は Student-testを用いた。

\section{結 果}

1）経口糖負荷後における血糖値の変動（図 1 )

コントロール群に晾ける空腹時血糖值は, $98 \pm 6$ $\mathrm{mg} / \mathrm{dl}$ で糖負荷後15分值 $122 \pm 6 \mathrm{mg} / \mathrm{dl}, 30$ 分值139土 $4 \mathrm{mg} / \mathrm{dl}, 60$ 分値 $156 \pm 4 \mathrm{mg} / \mathrm{dl}, 90$ 分値 $132 \pm 11 \mathrm{mg} /$ $\mathrm{dl}, 120$ 分值 $123 \pm 10 \mathrm{mg} / \mathrm{dl}$ と推移した。

術前食道癌患者では, 空腹時血糖値は, $86 \pm 1 \mathrm{mg} /$ dl で糖負荷後15分值 $131 \pm 8 \mathrm{mg} / \mathrm{dl} ， 30$ 分値 $158 \pm 8$ $\mathrm{mg} / \mathrm{dl}$ で, 60 分値 $176 \pm 10 \mathrm{mg} / \mathrm{dl}, 90$ 分值 $163 \pm 9 \mathrm{mg} /$ $\mathrm{dl}, 120$ 分值 $129 \pm 6 \mathrm{mg} / \mathrm{dl}$ と推移した。

術後食道癌患者の空腹時血糖値は $90 \pm 4 \mathrm{mg} / \mathrm{dl}$ で, 糖負荷後15分值 $157 \pm 7 \mathrm{mg} / \mathrm{dl}, 30$ 分値 $194 \pm 8 \mathrm{mg} /$ $\mathrm{dl}, 60$ 分値 $188 \pm 7 \mathrm{mg} / \mathrm{dl}, 90$ 分值 $141 \pm 5 \mathrm{mg} / \mathrm{dl}, 120$

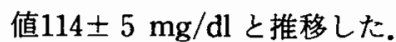

2）経ロ糖負荷後における血中インスリン分泌動態
（図 2）

コントロール群では，空腹時血中インスリン值は $11 \pm 1 \mu \mathrm{u} / \mathrm{ml}$ で, 糖負荷後15分値45土 $4 \mu \mathrm{u} / \mathrm{ml}, 30$ 分 値 $67 \pm 4 \mu \mathrm{u} / \mathrm{ml}, 60$ 分值 $84 \pm 5 \mu \mathrm{u} / \mathrm{ml}, 90$ 分値 $65 \pm 10$ $\mu \mathrm{u} / \mathrm{ml}, 120$ 分値 $61 \pm 12 \mu \mathrm{u} / \mathrm{ml}$ と推移した。

図 1 経口糖負荷後における血糖値の変動（Means士 SEM)

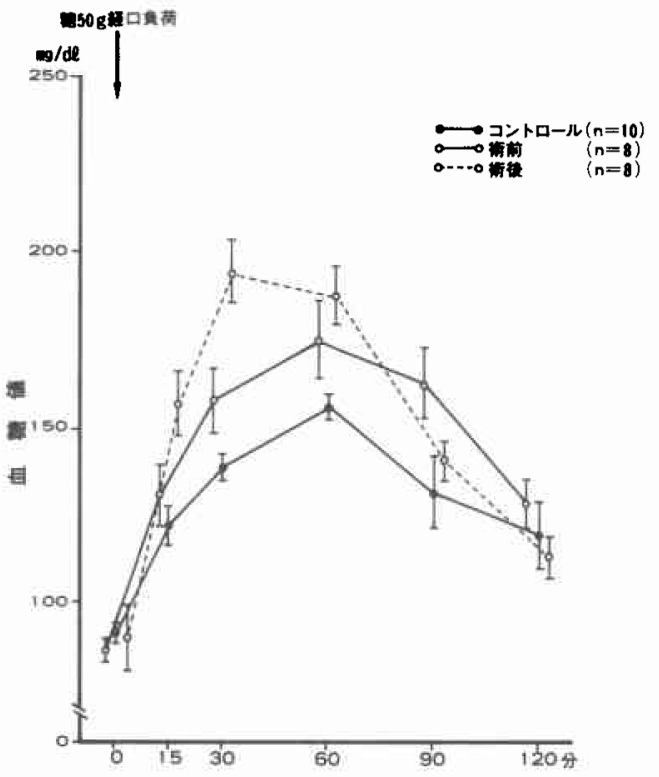

図 2 経口糖負荷後における血中インスリン分泌動 態 (Means \pm SEM)

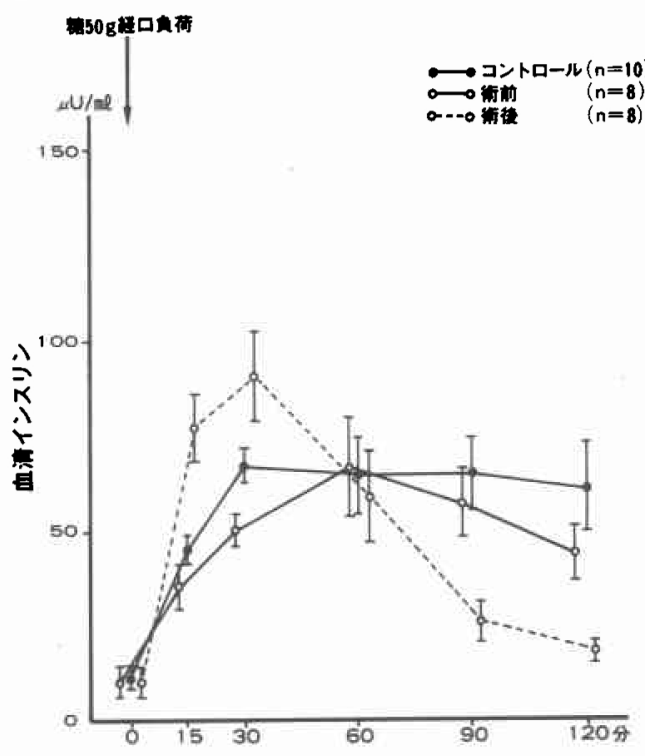


術前食道癌患者では，空腹時血中インスリン值は $10 \pm 1 \mu \mathrm{u} / \mathrm{ml}$ で, 糖負荷後 15 分値 $35 \pm 4 \mu \mathrm{u} / \mathrm{ml}, 30$ 分 值 $50 \pm 3 \mu \mathrm{u} / \mathrm{ml}, 60$ 分值 $66 \pm 12 \mu \mathrm{u} / \mathrm{ml}, 90$ 分値 $57 \pm 8$ $\mu \mathrm{u} / \mathrm{ml}, 120$ 分值 $44 \pm 6 \mu \mathrm{u} / \mathrm{ml}$ と推移した。

術後食道癌患者では, 空腹時血中インスリン值は $10 \pm 1 \mu \mathrm{u} / \mathrm{ml}$ で, 糖負荷後 15 分值 $78 \pm 8 \mu \mathrm{u} / \mathrm{ml}, 30$ 分 值 $91 \pm 11 \mu \mathrm{u} / \mathrm{ml}, 60$ 分 值 $59 \pm 8 \mu \mathrm{u} / \mathrm{ml} 90$ 分 值 $26 \pm 4$ $\mu \mathrm{u} / \mathrm{ml} 120$ 分値 $18 \pm 2 \mu \mathrm{u} / \mathrm{ml}$ と推移した。

以上のごとく糖負荷後 60 分までは，インスリン分泌 は, 術前に比較して有意に増加し $(\mathrm{P}<0.01) 60$ 分後は, インスリン分泌は低下した $(\mathrm{P}<0.01)$.

3）術前, 術後における insulinogenic index ( $\Delta \mathrm{G})$ について（図3）

グルコース負荷後の血糖上昇に対する血中インスリ ン上昇の割合が非糖疗病に比べ糖㽷病で低下している ことがSeltzer ${ }^{7}$, Cerasi ${ }^{8)}$ らよって認められており， とくに糖負荷後 30 分間における $(\Delta \mathrm{IRI} / \Delta \mathrm{G})$ は糖尿病 を示す指標となると言われている.私達は, コントロー 儿群, 食道癌患者術前, 術後について検討を加えた。 コントロール群では $1.31 \pm 0.13$, 術前患者では, $0.61 \pm$ 0.11 , 術後患者では $0.75 \pm 0.14$ となり, コントロール 群に比較して術前, 術後ともに, insulinogenic index は低下していた。 なお insulinogenic index は, 正常值 は0.8以上であり，確実な糖尿病では 0.4 以下であると 言われている910).

4）経口糖負荷後における血中グルカゴン分泌動態 (図 4 )

図 3 術前, 術後に括ける insulinogenic lndex.

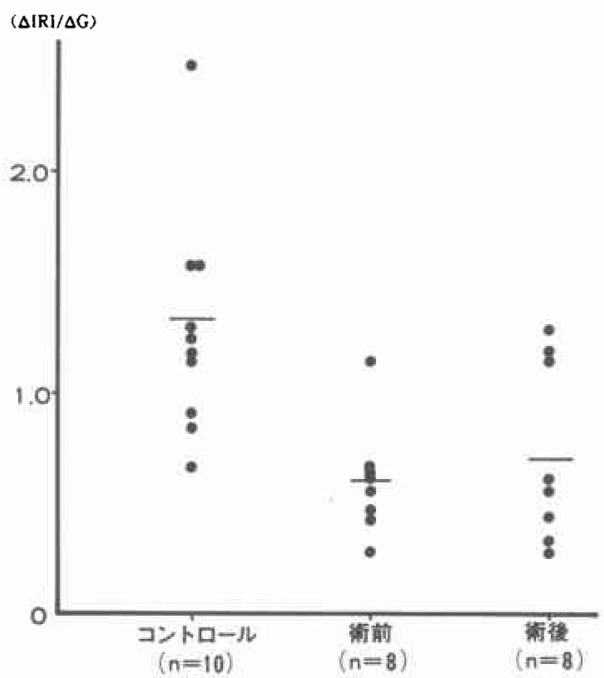

図 4 経口糖負荷後に抢ける血中グルカゴン分泌動態 (Means $\pm \mathrm{SEM}$ )

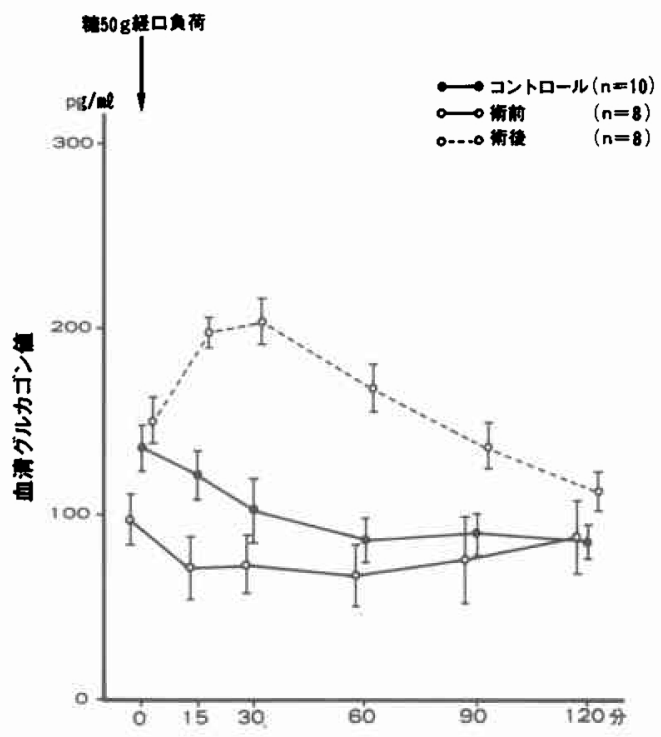

コントロール群では, 空腹時血中グルカゴン值は $136 \pm 15 \mathrm{pg} / \mathrm{ml}$ で, 糖負荷後 15 分値 $121 \pm 15 \mathrm{pg} / \mathrm{ml}, 30$ 分 値 $101 \pm 18 \mathrm{pg} / \mathrm{ml} ， 60$ 分値 $87 \pm 13 \mathrm{pg} / \mathrm{ml}, 90$ 分値 $91 \pm 12$ $\mathrm{pg} / \mathrm{ml}, 120$ 分值 $85 \pm 11 \mathrm{pg} / \mathrm{ml}$ と推移した。

術前患者では，空腹時血中グルカゴン値は98 011 $\mathrm{pg} / \mathrm{ml}$ で, 糖負荷後 15 分値 $71 \pm 13 \mathrm{pg} / \mathrm{ml}, 30$ 分値 $73 \pm 14$ $\mathrm{pg} / \mathrm{ml}, 60$ 分値 $68 \pm 14 \mathrm{pg} / \mathrm{ml}, 90$ 分值 $76 \pm 19 \mathrm{pg} / \mathrm{ml} 120$ 分値 $88 \pm 13 \mathrm{pg} / \mathrm{ml}$ と推移した。

術後患者では，空腹時血中グルカゴン値は $150 \pm 100$ $\mathrm{pg} / \mathrm{ml}$ で，糖負荷後 15 分值 $198 \pm 6 \mathrm{pg} / \mathrm{ml}, 30$ 分值 $204 \pm 10 \mathrm{pg} / \mathrm{ml}, 60$ 分值 $169 \pm 9 \mathrm{pg} / \mathrm{ml}, 90$ 分値 $135 \pm 10$ $\mathrm{pg} / \mathrm{ml}, 120$ 分值 $113 \pm 7 \mathrm{pg} / \mathrm{ml}$ と推移した。経口糖負

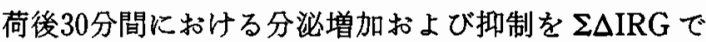
示すと図 5 のごとくで, コントロール群 $-464 \pm 117 \mathrm{pg}$ $\mathrm{min} / \mathrm{ml}$ 術前 $-616 \pm 110 \mathrm{pg} . \mathrm{min} / \mathrm{ml}$ 術後 $+861 \pm 93 \mathrm{pg}$. $\mathrm{min} / \mathrm{ml}$ と術後はグルカゴン分泌は増加していた $(\mathrm{P}<$ 0.01 ).

5）食道手術前後におけるインスリン,グルカゴンの モル比の椎移（図 6)

血糖值は, 門脈血中インスリン,グルカゴンのモル 比により左右されるといわれて扣り，また，末梢血中 インスリン，グルカゴンのモル比がこれに代用しえる と言われているので，末梢血中インスリン，グルカゴ ンのモル比の推移を, コントロール群, 術前, 術後で 検討した。コントロール群では, 空腹時血中 $\mathrm{I} / \mathrm{G}$ 比は, 
図 5 経口糖負荷後30分間における $\mathrm{AIRG}$

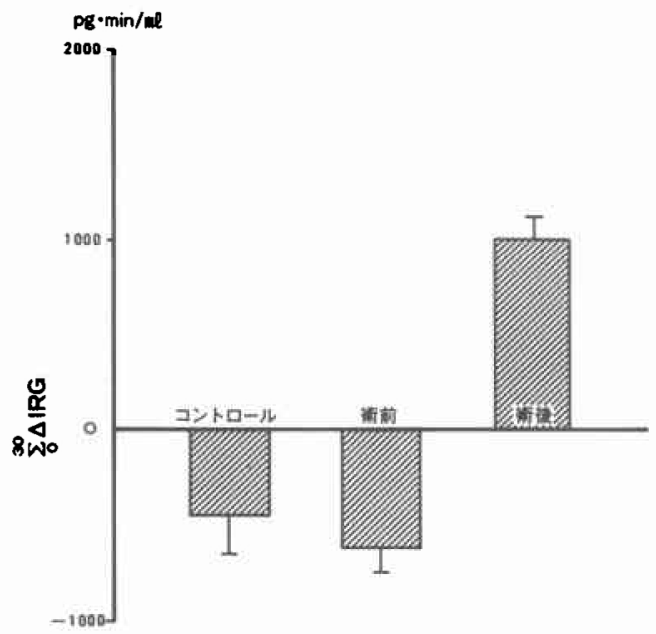

図 6 食道手術前後におけるインスリン，グルカゴン のモル比の推移 (Means士SEM)

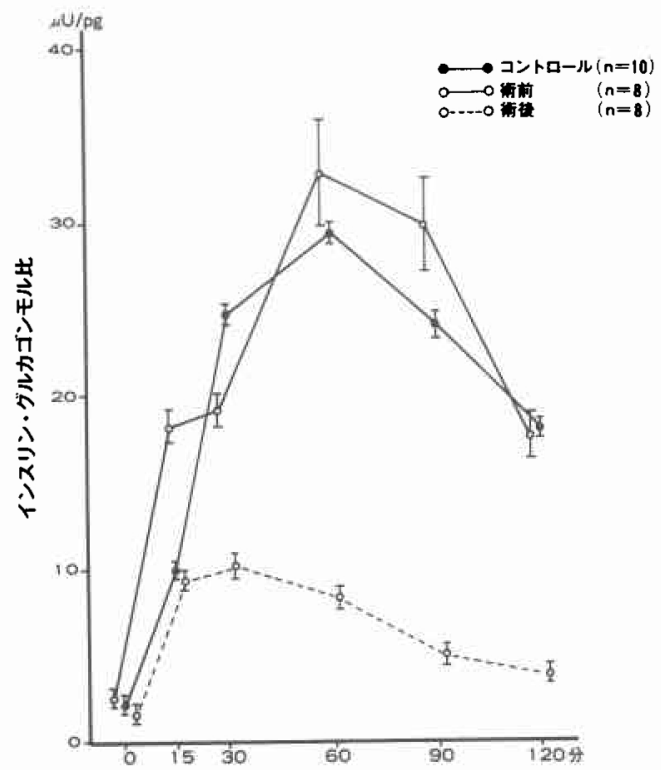

$2.0 \pm 0.1$ で糖負荷後 60 分値 $29.5 \pm 2.4,120$ 分値 $18.0 \pm$ 1.5 と推移した. 術前患者では, 空腹時血中 $\mathrm{I} / \mathrm{G}$ 比は $2.4 \pm 0.4$ で, 糖負荷後60分值 $33.1 \pm 10.0,120$ 分值 $17.5 \pm 5.0$ と推移した. 術後患者では, 空腹時血中 $I / G$

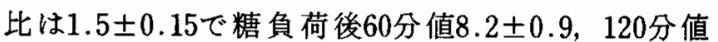
$3.9 \pm 0.8$ と推移した. 以上のごとく術後 $I / G$ 比は著明 に低下した（P<0.01）。

6) 経静脈的糖負荷後に拈ける血糖值,血中インスリ
図 7 経静脈的糖負荷後における血糖値, 血中インス リン值, グルカゴン值の変動（Means \pm SEM）
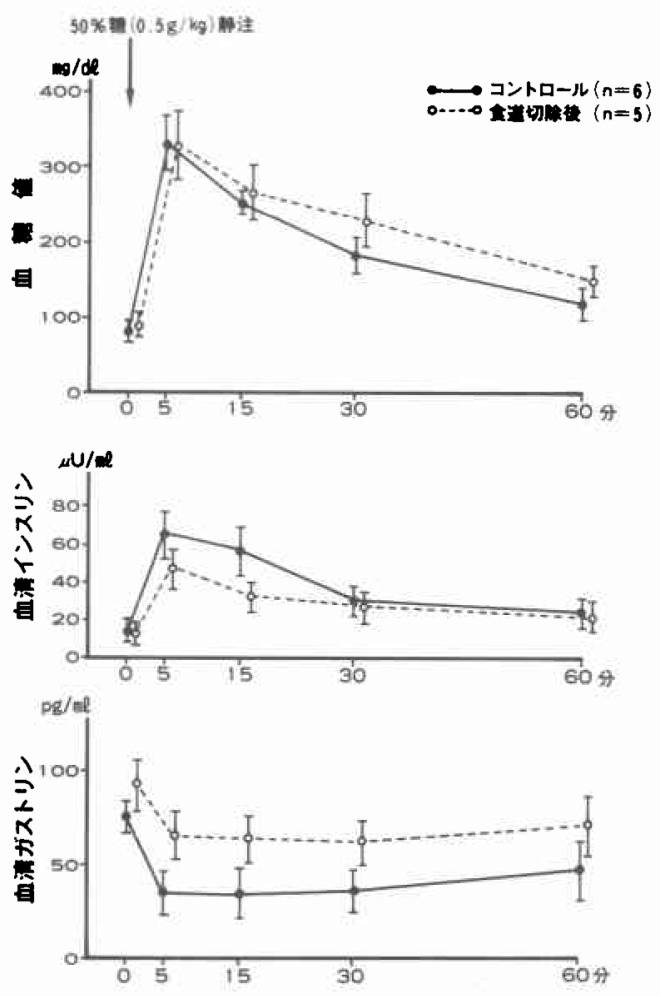

ン値, グルカゴン値の変動（図 7 )

血糖値について：コントロール群では, 空腹時血糖 值は79土 $2 \mathrm{mg} / \mathrm{dl}$ で，糖負荷後 5 分で, $333 \pm 30 \mathrm{mg} /$ $\mathrm{dl}, 15$ 分值 $251 \pm 11 \mathrm{mg} / \mathrm{dl}, 30$ 分值 $181 \pm 16 \mathrm{mg} / \mathrm{dl}, 60$ 分 値 $117 \pm 13 \mathrm{mg} / \mathrm{dl}$ と推移した. 食道手術患者では, 空腹 時血糖值は, $90 \pm 5 \mathrm{mg} / \mathrm{dl}$ で糖負荷後 5 分で $329 \pm 38$ $\mathrm{mg} / \mathrm{dl}, 15$ 分値 $269 \pm 30 \mathrm{mg} / \mathrm{dl}, 30$ 分值 $232 \pm 27 \mathrm{mg} / \mathrm{dl}$, 60 分值 $150 \pm 16 \mathrm{mg} / \mathrm{dl}$ と推移した。

血中インスリン值について：コントロール群では, 空腹時血中インスリン値は $13 \pm 2 \mu \mathrm{u} / \mathrm{ml}$, 糖負荷後 5 分で $66 \pm 10 \mu \mathrm{u} / \mathrm{ml}, 15$ 分値 $56 \pm 9 \mu \mathrm{u} / \mathrm{ml}, 30$ 分値 $30 \pm$ $5 \mu \mathrm{u} / \mathrm{ml}, 60$ 分値 $23 \pm 4 \mu \mathrm{u} / \mathrm{ml}$ と推移した. 食道切除 後の患者では, 空腹時血中インスリン值は, $11 \pm 1 \mu \mathrm{u} /$ $\mathrm{ml}$ で, 糖負荷後 5 分で $49 \pm 7 \mu \mathrm{u} / \mathrm{ml}, 15$ 分值 $31 \pm 5$ $\mu \mathrm{u} / \mathrm{ml}, 30$ 分值 $29 \pm 6 \mu \mathrm{u} / \mathrm{ml}, 60$ 分値 $22 \pm 3 \mu \mathrm{u} / \mathrm{ml}$ と 推移した。コントロール群と比較するとインスリン分 泌は低値であった。

血中グルカゴン分泌について：コントロール群で は, 空腹時血中グルカゴン値は76士 $5 \mathrm{pg} / \mathrm{ml}$ で, 糖負 荷後 5 分で $36 \pm 6 \mathrm{pg} / \mathrm{ml}, 15$ 分値 $35 \pm 5 \mathrm{pg} / \mathrm{ml}, 30$ 分 
值 $36 \pm 6 \mathrm{pg} / \mathrm{ml}, 60$ 分値 $46 \pm 7 \mathrm{pg} / \mathrm{ml}$ と推移した。食 道切除後の患者では, 空腹時血中グルカゴン值は, $94 \pm$ $13 \mathrm{pg} / \mathrm{ml}$ で糖負荷後 5 分で $67 \pm 9 \mathrm{pg} / \mathrm{ml}, 15$ 分値 $67 \pm$ $100 \mathrm{pg} / \mathrm{ml}, 30$ 分值 $63 \pm 9 \mathrm{pg} / \mathrm{ml}, 60$ 分值 $71 \pm 13 \mathrm{pg} / \mathrm{ml}$ と推移し、コントロール群に比較して分泌抑制度は低 下する傾向を示した。

\section{考案}

食道癌患者では，高齢者が多く，したがって糖負荷 試験では，術前より糖尿病型もしくは，境界型を示す ものが大部分を示すと言われている ${ }^{11}$. 食道癌患者で は，術前栄養状態が不良であり，術後も長期に経口摂 取不能の期間が長いため, 高カロリーを行う機会がふ 兄ており，糖負荷過㮃による高滲透王性非ケトン性昏 睡 ${ }^{121313}$ ，糖過郵による肝障害など(14) 16)が報告されてお り, 食道癌手術と糖尿病の合併症として, 心, 腎, 血 管障害, 感染による肺合併症縫合不全などの合併症が 増加するといわれている，そこで食道癌手術前後にお いて糖代謝之膵内分泌機能について十分把握し，これ に対処すべきであると考えている。

糖尿病の発生については, インスリン分泌機能低下 の見地からその多くが検討されてきたが, Unger ${ }^{1)}$, Müller $^{2)} ら は$, 正常人と糖尿病患者との間には, インス リン值のみならず,グルカゴン值にも差異が認められ, ある種の糖尿病患者では，相対的グルカゴン過剩下に あると指摘した。食道癌患者の術前術後の糖代謝異常 について,インスリン, グルカゴン分泌の面から検討 したものは，現在のところ報告されて和らず，われわ れは, 食道癌患者の術前, 術後のインスリン, グルカ ゴン分泌の面から食道癌手術前後の糖代謝について検 討を加えた.コントロール群, 食道癌患者の経口糖負 荷試験における，血糖曲線では(図 1)，空腹時血糖值 は, いずれも $100 \mathrm{mg} / \mathrm{dl}$ 以下であったが, 食道癌患者で は，術前術後で境界型を示し，コントロール群之比較 すると, 15 分, 30 分, 60 分で有意 $(\mathrm{P}<0.01)$ に障害さ れていた，術前，術後を比較すると，糖代謝は障害さ れる傾向を示した。

インスリン分泌についてみると(図 2)，インスリン 分泌は, コントロール群に比較すると術前では30分で 有意 $(\mathrm{P}<0.01)$ に分泌低下していたが, 術後では, 糖 負荷後60分までは，インスリン分泌は過㮃であるが， 60分以後は分泌反応は低下していた。 その成因につい ては, 食道切除後は, 食物は直接胃に入いり, 十二指 腸, 空腸への流出が早くなり糖吸収が促進される為で あると思われる ${ }^{17)}$ 。を 60 分後のインスリン分泌の低
下は60分以後の血糖値の急速な低下によるものと思わ れる(図1)。

糖負荷後30分間に怙ける insulinogenic index は(図 3). 糖尿病を示す一つの指標になると言われている が778), コントロール群に比較して, 食道癌患者では, 術前すでに糖尿病もしくは境界型の pattern を示して おり，術後はさらに障害される傾向を示した。

次にグルカゴン分泌反応を見ると（図４），食道癌患 者の術前，術後を比較すると，空腹時15分， 30 分， 60 分で有意 $(\mathrm{P}<0.01)$ に分泌過剩であり, 糖負荷後 30 分

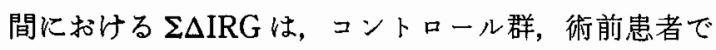
は, グルカゴン分泌は抑制されるのに反し術後は，グ ルカゴン分泌は促進されている。このことは, 食道切 除に際し, 左右の全幹迷走神経切除を行ったことが, グルカゴン分泌に影響を与えているものと推測され る ${ }^{18)}$. 事実私達が行った胃全摘患者に执いてもグルカ ゴン分泌過㮃をむたらしたのである ${ }^{19}$. この様に食道 切除患者では，互いに拮抗するインスリン，グルカゴ ンは過剩に分泌されていたが，糖代謝にいかなる影響 を技よほすすかを検討する必要がある。そこで

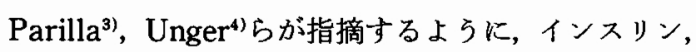
グルカゴンのモル比について検討してみた（図 6). 食 道切除患者では, 糖負荷後 30 分以後では, 明らかに I/ $\mathrm{G}$ モ比は低下して招り，食道切除患者に拈ける糖代 謝異常にグルカゴン分泌過剩が関与していることを示 唆している. 次にコントロール群と食道切除患者に $50 \%$ ブドウ糖を $0.5 \mathrm{~g} / \mathrm{kg}$ 静注した際の血糖值インスリ ン值, グルカゴン值の変動をみたのが図 7 であるが, 血糖値には差異はないが, 糖負荷後の血中インスリン 分泌反応は，術後で障害されていた。をた，糖負荷後 におけるグルカゴン分泌抑制反応は術後で低下してい た. 以上のごとく, 経静脈負荷試験では幹迷切の影響 を強く受けることが判明した。

\section{結 論}

食道癌患者では, 術前よりすでに糖尿病ないしは, 境界型を示するのが多く, 術後は, 経口的糖負荷試験 では,グルカゴン分泌過剩を来し，糖質代謝に影響を およぼしていることが判明した，経静脈負荷では，血 中インスリン, 分泌反応は術後で低下し, 血中グルカ ゴン分泌抑制反応も低下していた。

本論文の要旨は, 第22回日本消化器病学会秋季大会(鹿児 島）に拈いて発表した。

\section{文献}

1) M̈ller, W.A., and Faloona, G.A.: Abnormal 
alpha cell function in diabetes. New Engl J Med 283 : 109-115, 1970

2) Unger, R.H., Aguillar Paradae, Müller, W.A., et al: Studies of Alpha cell function in normal and diabetic subjects. J Clin Invest 49 : $839-848,1970$

3) Parilla, R., and Goodman, M.N .: Effect of glucagon, insulin ratio on hepatic metabolism. Diabetes 23:725-731, 1974

4) Unger, R.H.: Glucagon and insulin, glucagon ratio in diabetic and other catabolic illness. Diabetes 20:834-839, 1971

5）白羽 誠，久山 健：全胃後綎隔ルート挙上によ 万食道再建術。外科診療 $19 ： 112-114,1977$

6) Unger, R.H., and Eisentraut, A, : Glucagon. In Hormones in blood. C. Grey and A. Bacharach, editors. Academic press, Inc, New York. 2nd ed. 1:83-128, 1967

7) Seltzer H.S., and Smith W.L.: Plasma insulin activity after glucose An index of insulinogenic reserve in normal and diabetic man. Diabetes $8: 417-427,1959$

8) Cerasi, E., and Efendic, S,: Dose-Response relation between plasma-insulin and bloodglucose levels during oral glucose loads in Prediabetic and diabetic subjects. Lancet 14 : 794-797, 1973

9）小坂樹德：血中インスリンの臨床的意義. 日医師 会誌 $66: 705-716,1971$

10）羽倉棱子, 秋田茂夫：糖尿病緩解時に招ける血中 インスリン動態. 糖尿病 $13: 440-446,1970$
11）森 昌造, 渡辺登志男, 酒井信光ほか：食道癌の外 科治療における耐桾能試験の意義. 外科 40 ： $664-670,1978$

12) Sament, S. and Schwartz, M.S.: Severe diabetic stupor without ketosis. South Africa Med J 31 : 893-894, 1957

13) Dudrick, S.J., Macfadye, B.V., Vanburen, C.T., et al: Parenteral hyperalimeotation, metabolic problems and solutions. Ann Surg $176: 259-264,1972$

14) Roders, B.M., Hollenbeck, J.I., Donnelly, W.H., et al: Intrahepatic cholestasis with parenteral alimentation. Amer J Surg $131: 149-155,1976$

15) Grant, J.Z., Cox, C.E., Kleinman, L.M., et al : Serum hepatic enzym and Bilirubin elevations during parenteral nutrition. Surg Gyen Obste $145: 573-580,1977$

16）池田義和, 过本雅一, 岡田 正ほか：高カロリ一輸 液 $(\mathrm{V})$, 高かロリー輸液が肝荿に与える影響につ いて。外科治療 $30: 337-244,1974$

17) Williams, R.H.: Textbook of endocrinology, fifth edition, Philadelphia, W.B. Saunder, S.P., 1974, p641-642

18) Sudo, T., Kawamura, M., Umemura, H., et al : Effects of vagotomy and gastrectomy on pancreatic glucagon release. Ann Surg 194: $23-28,1981$

19）須藤峻章, 河村正生, 西野幹夫ほか：胃全摘後の再 建術式上りみた苹内分泌機能に関する研究。日外 会誌 $82 ： 162-168,1981$ 